\title{
Práticas sociais, discurso e arquivo: a mídia e os gestos de leitura subjacentes
}

\author{
Belmira Magalhães ${ }^{1}$ \\ Helson F. da Silva Sobrinho ${ }^{2}$
}

\begin{abstract}
Resumen: En este artículo, proponemos, a partir de la perspectiva del Análisis del Discurso pecheuteana, revisitar la importancia de la noción de Archivo, analizando discursos vehiculados en el sitio de la emisora Rede Globo "memóriaglobo.globo.com". Nuestro camino de análisis destacó la imbricación entre prácticas sociales establecidas y la formulación y el gesto de lectura del archivo, lo que demuestra el carácter histórico e ideológico del funcionamiento de los archivos, que, como toda praxis social, produce silenciamientos y efectos de sentidos que, en sus discursividades subyacentes, actúan también en el antagonismo de clases existentes en la sociedad brasileña.
\end{abstract}

Palabras clave: discurso; archivo; sujeto; historia.

Resumo: Neste artigo propomos, a partir da perspectiva da Análise de Discurso pecheutiana, revisitar a importância da noção de Arquivo, analisando discursos veiculados no site da Rede Globo "memóriaglobo.globo. com". Nosso caminho de análise salienta a imbricação entre práticas sociais determinadas e a formulação e o gesto de leitura do arquivo, evidenciando o caráter histórico e ideológico do funcionamento dos arquivos, que, como toda práxis social, produz silenciamentos e efeitos de sentidos. Estes, em suas discursividades subjacentes, também atuam no antagonismo de classes existente na sociedade brasileira.

Palavras-chave: discurso; arquivo; sujeito; história.

Introdução

As práticas sociais ocorridas desde o Inverno Brasileiro (junho de 2013) possibilitaram um retorno à memória discursiva a partir de retomada de Arquivo de certos acontecimentos históricos no Brasil que envolvem política e mídia. Oportunamente, nesse entremeio, disseram-nos que "O Gigante finalmente acordou", remetendo-nos a vários caminhos de sentidos contraditórios que exigem gestos de leituras capazes de investigar a transparência da linguagem, os mecanismos ideológicos e as artimanhas do poder econômico e político atuante na imprensa brasileira.

Para questionar esse efeito de evidência de que o Brasil "finalmente" acordou de um sono, ou mesmo de uma letargia, é preciso perguntar: quem de fato acordou? Como acordou? E para que acordou? Ou seja, é preciso direcionar o olhar para além da obviedade desses enunciados aparentemente inequívocos.

Não obstante, "coincidentemente", a mídia também “acordou” para noticiar as manifes-

1 Doutora em Letras e Linguística. Professora e pesquisadora da Universidade Federal de Alagoas (UFAL).

2 Doutor em Letras e Linguística. Professor e pesquisador da Universidade Federal de Alagoas (UFAL). 
tações nas/das ruas, mas, em seu gesto de interpretação, passou rapidamente a denominá-las de "manifestações pacíficas", o que por efeito de deslize direciona para sentidos de manifestações "pacatas", "tranquilas", "sossegadas" etc. Ou seja, efeitos de memória de um "homem cordial" ou de um "pacato cidadão", forjada na constituição identitária brasileira e que hoje é retomada visando à defesa da "democracia". Isso permite que se façam manifestações desde que se mantenham a "ordem e o progresso".

A fim de estudar a relação entre discurso, arquivo e práticas históricas, nos valeremos mais especificamente do site da Rede Globo, "memóriaglobo.globo.com", no link "Erros". Nesse trajeto inicial já é possível nos depararmos com os mecanismos da informática, e ao mesmo tempo, com os significantes "memória" e "erros". Trata-se de um retorno a uma memória histórica por meio de retomadas de arquivos da Rede Globo. Esse gesto (a mídia pela mídia) "coincide" com o período das manifestações de junho de 2013. Poder político e econômico, mídia e história do Brasil se entrecruzam, parecendo inicialmente que se confrontam por meio de retificações de "erros". Isso revela determinados "acertos e desacertos" na/da posição sujeito ideológico-discursivo que, historicamente, as instituições da grande imprensa assumem diante das ameaças e possíveis favores advindos dos "donos do poder". Afinal, como diz Pêcheux (1997, p. 60), "Não faltam boas almas se dando como missão livrar o discurso de suas ambigüidades, por um tipo de 'terapêutica da linguagem' que fixaria enfim o sentido legítimo das palavras, das expressões e dos enunciados".

Aqui surge outra questão na leitura desse arquivo, pois quais são as consequências desse tão repentino retorno de arquivos da mídia pela própria mídia, especificamente de discurso "sobre" determinados acontecimentos histórico-políticos no Brasil?

Iniciamos nossa reflexão com o alerta de Pêcheux de que, normalmente, esses gestos entre os quais incluímos esse discurso da mídia (os discursos de mea culpa) tendem ao policiamento dos enunciados, à normalização asséptica da leitura e do pensamento e ao apagamento seletivo da memória histórica (PÊCHEUX, 1997). A nosso ver, isso tem sérias consequências nas práticas sociais, porque, enquanto discurso, as materialidades da ideologia orientam as ações e as práticas, cumprindo funções específicas tanto para a reprodução como para a transformação das relações sociais.

É nesse caminho, pois, que nos reencontramos com a perspectiva marxiana que, na síntese entre objetividade e subjetividade, ressalta que a única forma de se perceber a veracidade de uma postulação teórica é a sua realização no real da história, ou seja, sempre como um acontecimento post festum. Assim, na segunda tese Ad Feuerbach, Marx afirma que

A questão de atribuir ao pensamento humano uma verdade objetiva não é uma questão teórica, mas sim uma questão prática. É na práxis que o homem precisa provar verdade, isto é, a realidade e a força, a terrenalidade de seu pensamento. A discussão sobre a realidade ou a irrealidade do pensamento - isolado da práxis - é puramente escolástica (MARX, 2002, p. 100)

Essas práticas sociais que vêm ocorrendo desde junho de 2013 no Brasil ressaltam a necessidade de se rever arquivos e analisá-los para além de sua imediaticidade. Reafirmam, assim, a teoria marxiana, quando esta ressalta como única forma de compreender o real da história uma análise que leve em consideração o movimento da própria história em sua totalidade complexa. Isso significa que não podemos isolar a análise de discurso da sua práxis, pois é grande o risco de se abstrair o caráter material do sentido que ali se manifesta e atua dialeticamente nas relações sociais contraditórias. Eis o trajeto desta investigação. 


\section{Práxis social e Arquivo}

Para Pêcheux (1997, p. 57), a noção de Arquivo deve ser "entendida no sentido amplo de "campo de documentos pertinentes e disponíveis sobre uma questão"; porém, para salientar o caráter histórico, cultural, político e ideológico do arquivo, Pêcheux aprofunda a investigação e versa sobre a questão da leitura do arquivo como também sobre o modo de tratamento desses documentos textuais. Especialmente, é o gesto de leitura subjacente na discursividade do arquivo que chama a atenção de Pêcheux, já que ele entende que tanto a tradição literária como a científica contornam a questão da leitura e as maneiras diferentes e contraditórias de se ler o arquivo. Subjazem leituras implícitas, silenciamentos, apagamentos que têm a ver com o trabalho da memória histórica e também com as gestões dos aparelhos e instituições de poder que produzem evidências de sentidos, sempre tidos como "a leitura" literal, verdadeira. Adverte-nos Pêcheux (1997, p. 63): "É esta relação entre língua como sistema sintático intrinsecamente passível de jogo, e a discursividade como inscrição de efeitos lingüísticos materiais na história, que constitui o nó central de um trabalho de leitura de arquivo".

O trabalho de leitura de arquivo necessita que se desconfie do que parece ser óbvio e “dado a ver", mostrando-se, ainda, como transparente e inquestionável. Orlandi (1996, p. 30) corrobora ser a interpretação o lugar próprio da ideologia. Acrescenta também que ela "tem sua espessura, sua materialidade - mas nega-se, no entanto, à interpretação e suas condições no momento mesmo em que ela se dá e se tem a impressão do sentido que se 'reconhece', já lá".

Assim, todo arquivo é uma prática social constituída por gestos de interpretação que, como tal, tem como premissas as condições materiais de produção que permitiram sua efetivação e a ideologia predominante na sua elaboração. Um arquivo, qualquer que seja ele, é o resultado de práticas sócio-históricas, e por isso passível de silenciamentos conscientes e de equívocos inconscientes por parte dos sujeitos ${ }^{3}$ que o elaboram e o organizam. Por outro lado, também a manipulação do arquivo se submete a todas essas determinações que sofre o sujeito que a realiza. Como diz Mariani (2010, p. 89), sobre a organização do arquivo "há sentidos colocados para serem lidos e repetidos [...] e há também sentidos recalcados, silenciados interditados, censurados. Podemos pensar, então, que nos arquivos se inscrevem sintomas da época em que foram organizados e é com esses sintomas que um pesquisador se depara".

Nesse sentido, como em qualquer prática social, não há neutralidade na composição nem na leitura do arquivo, pois os conflitos de classes ${ }^{4}$ seguirão determinando as práticas ideológicas de quem administra, classifica e ordena os documentos, e também de quem consulta os arquivos, em seus gestos de leitura interpretação.

Na sociedade do capital, e sua barbárie, é habitual compreender a história como chegada ao fim último, ou seja, uma sociedade capitalista que apesar de suas contradições pode se mostrar "democrática", "livre" e "igualitária", com alguns aperfeiçoamentos que advêm das reformas. Essa convicção parece orientar a leitura dos arquivos como em busca de justificativas para o "fim da história" e da "ideologia". Sob essa alegação tenta-se apagar os conflitos antagônicos derivados das relações sociais de classes como se elas não existissem mais, e o que ocorre é tido tão só como "desentendimentos" derivados de equívocos que podem ser "muito bem esclarecidos" mediante as "palavras".

3 Sujeito aqui não se refere a um indivíduo, mas a posição sujeito.

4 Estamos analisando uma sociedade dividida em classes social, especificamente a sociedade contemporânea, subsumida à lógica de mercado, que tem o valor de troca, com a consequente exploração da mais-valia, visando à sua reprodução. 
É, pois, preciso retomar a história, como ela se dá na formação social capitalista. No texto O 18 de Brumário de Luís Bonaparte, Marx afirma: "Em alguma passagem de suas obras, Hegel comenta que todos os grandes fatos e todos os grandes personagens da história mundial são encenados, por assim dizer, duas vezes. Ele se esqueceu de acrescentar: a primeira vez como tragédia, a segunda como farsa" (MARX, 2011, p. 25). Essa análise de Marx nos faz refletir sobre as questões da sociedade capitalista atual e sua concepção de Estado, práticas político-democráticas que são produtos das relações de base material. Se a história aparece como tragédia e/ou como farsa, esse processo resulta das contradições e lutas de classes que estão subjacentes a essas manifestações fenomênicas. Marcuse (2011) reafirma a importância e pertinência dessa obra de Marx, pensando também na sociedade burguesa do século XX:

\begin{abstract}
A análise que Marx faz do processo de evolução da Revolução de 1848 para o domínio autoritário de Luís Bonaparte antecipa a dinâmica da sociedade burguesa tardia: a liquidação do seu período liberal que se consuma em razão da sua própria estrutura. [...] Aqui, liberdade e igualdade têm um sentido bem diferente - um sentido que ameaça a dominação estabelecida. A generalização e a realização da liberdade não são mais do interesse da burguesia; isso já é "socialismo". [...] A classe dominante se mobiliza para liquidar não só o movimento socialista, mas também as suas próprias instituições, que entraram em contradição com o interesse da propriedade e do negócio: os direitos civis, a liberdade de imprensa, a liberdade de reunião, o direito ao sufrágio universal foram sacrificados a esse interesse para que a burguesia pudesse, sob a proteção de um governo forte e irrestrito, dedicar-se aos seus negócios privados [...] $\mathrm{Na}$ sua ascensão, a burguesia mobilizou as massas e reiteradamente as traiu e abateu. A sociedade capitalista em desenvolvimento precisa contar de modo crescente com as massas, integrá-las na normalidade econômica e política, torná-las capazes de pagar e (até certo ponto) inclusive de governar. O Estado autoritário necessita de uma base democrática de massas; o líder deve ser eleito pelo povo, e ele o é. $O$ direito ao sufrágio universal, que a burguesia nega de facto e depois também de iure, torna-se a arma do Poder Executivo autoritário contra os grupos renitentes da burguesia. (p. 9-12)
\end{abstract}

Hoje, acrescentaríamos que a farsa se transformou em cinismo (ŽIŽEK, 2011), sempre a serviço da burguesia. Não é à toa que na análise de Marx sobre a função do Estado nas sociedades de classes, ele mostra como o poder político nessas sociedades está sempre reproduzindo as explorações de classes que lhes são peculiares. Ele revela como a democracia e o golpe de Estado servem aos interesses das classes dominantes, para que se mantenha a ordem burguesa.

Quando transportamos o olhar dessa compreensão do Estado para os textos em análise neste artigo, constata-se que estamos, na sociedade regida pela lógica do capital, inscritos nos discursos dominantes dos valores de "igualdade", de "propriedade" e da "democracia"; e, de modo idêntico, nos efeitos da compra-venda de mercadorias, da exploração do trabalho e da coisificação do sujeito. Nesse ponto é preciso observar que esta questão da experiência histórica não está desvinculada do modo de leitura do Arquivo, pois não só margeia suas bordas, como constitui a essencialidade do fenômeno discursivo por meio de mecanismos ideológicos.

\title{
2 Erros e (des)acertos da mídia: a posição sujeito no retorno ao arquivo
}

Voltemos aos acontecimentos que nos mobilizaram para a realização da presente reflexão e nos permitiram uma maior compreensão da noção de Arquivo. Desde junho de 2013, o 
Brasil vem convivendo com protestos de rua que têm como base um chamamento realizado pelas redes sociais, a exemplo do que já vinha acontecendo em vários países do mundo. As ruas das principais cidades brasileiras se encheram de jovens que gritavam por melhores condições de vida, mais transparência, menos corrupção. Essas manifestações apresentam novidades em vários aspectos a serem estudados, entre eles: espontaneidade dos sujeitos; negação de direção partidária, inclusive com críticas a todos os partidos; diversidade de reivindicações; participação das redes sociais, tanto para convocar como para relatar o ocorrido, e com crítica direta à grande imprensa, que de início condenou abertamente as manifestações populares. Essa crítica é que nos interessa para nossa atual abordagem.

As críticas mais contundentes das manifestações se dirigiram à Rede Globo, que desde o início foi colocada como aliada do poder e acusada de ter apoiado o Golpe Militar de 1964, com cartazes e faixas que diziam: "A REALIDADE É DURA, A GLOBO APOIOU A DITADURA!". Essas práticas sociais fizeram com que a emissora promovesse uma revisão, ou mesmo uma retomada de seus arquivos de telejornais, numa tentativa de esclarecer, ou melhor, de se defender das acusações que lhe eram destinadas. Para isso, começou a ser confeccionado um "novo arquivo" que tenta justificar as atitudes anteriores desse conglomerado jornalístico, sempre com o objetivo de corrigir "erros" na tragédia do passado.

No site da emissora Globo (memoriaglobo.com), foi possível encontrar alguns caminhos de leitura sugeridos e/ou mesmo guiados pela própria emissora, por exemplo, o nome do site já apontava para "memória", ou seja, em nosso entender trata-se do "arquivo" da própria Instituição que estava sendo "dado" a ver/ler em vários links (Programas, Perfis, Mostras, Erros, Acusações falsas, Institucional). No entanto, dois links em especial nos chamaram a atenção, quais sejam: "Erros" e "Acusações falsas". Nesse momento, o foco de nossa análise incidirá no link "Erros".

A primeira visita ao arquivo Globo nos fez verificar no site a existência de três "Erros": 1. Golpe 1964; 2. Diretas já; 3 . Debate Collor $x$ Lula. O primeiro texto do arquivo sobre o Golpe de 1964 foi publicado em 31 de agosto de 2013; referia-se exatamente a uma justificativa do apoio ao Golpe Militar, considerando que foi um "erro" tal tomada de posição, sem dúvida, uma resposta diretamente às ruas, que apontavam a emissora como cúmplice das artimanhas do poder. No entanto, "curiosamente", na nossa última consulta ao arquivo do site memoriaglobo.globo.com, realizada em janeiro de 2014, constatamos que esse texto sobre o Golpe de 1964 não está mais disponível. Apenas os outros dois textos continuam "dados a ver" para o acesso do "internauta".

O fato do "desaparecimento" (ausência de um texto anteriormente presente) pode ser entendido como uma prática de acerto (conserto), mas é também revelador da gestão do/ no arquivo, pois o "erro" foi colocado e retirado depois de determinado tempo. $\mathrm{O}$ fato de esse texto não permanecer no arquivo sobre os "erros" (uma ausência) produz um silenciamento/censura (ORLANDI, 2002) capaz de provocar, no futuro, o "esquecimento" pelo redirecionamento dessa memória histórica de "apoio ao Golpe" 5.

Para o momento, resta-nos dirigir o olhar aos dois outros textos/“erros", não menos importantes, que serão o foco de nossa análise. O primeiro deles diz respeito ao tratamento dado às notícias sobre o movimento das "Diretas já" entre os anos de 1983 e 1984. O segundo documento refere-se ao debate no segundo turno da primeira eleição direta para presidente do Brasil após a ditadura militar e a sua edição "técnica" pelo jornal Hoje e pelo Jornal Nacional. É sobre esses dois textos de arquivo (documentos) que nos debruçaremos a partir de agora.

5 O leitor interessado poderá consultar a análise desse texto de arquivo em Magalhães e Silva Sobrinho (2014). 


\section{1 “Erro": Diretas Já. (1983/1984)}

O texto se inicia apresentando uma descrição sucinta do que foi o movimento das Diretas Já a partir da proposta de Emenda Constitucional, do deputado Dante de Oliveira. Em seguida, passa a colocar a posição/interpretação da Rede Globo sobre o acontecimento:

A Rede Globo acompanhou toda a movimentação política em torno da tramitação da
emenda Dante de Oliveira no Congresso. Ainda antes do lançamento da campanha, no
dia 29 de março de 1983, o Jornal Nacional apresentou uma matéria, de dois minutos e
16 segundos, informando que a Executiva do PMDB se reuniria na semana seguinte para
lançar o movimento. O repórter Antônio Britto entrevistou o líder do PMDB na Câmara,
deputado Freitas Nobre, que expôs a estratégia da oposição para aprovar o projeto.
Você pode ver a reportagem do Jornal Nacional clicando na imagem abaixo

Algumas estratégias discursivas podem ser ressaltadas nessa escrita, pois elas aparecem como se produzissem um efeito de verdade (esclarecimento) do fato:

- O noticiário da rede Globo se antecipou ao lançamento da campanha, "informando" sua data e proposta.

- Salienta o tempo de duração da matéria: dois minutos e 16 segundos.

- Disponibiliza um link para que os interessados cliquem na entrevista com o presidente do PMDB, na época, partido que comandava os acontecimentos.

Esse efeito de verdade parece dizer que o leitor pode ler e ver para constatar com seus próprios olhos a versão "certa" do acontecimento. Percebe-se, a partir do verbo empregado "informar", que há na matéria uma tentativa de mostrar ("você pode ver") apenas uma informação sobre os fatos, ou seja, a afirmação do não comprometimento em relação aos fatos, que inclusive são narrados na entrevista e não pelo sujeito jornalístico. Com a continuação dos textos, iremos perceber que essa primeira abordagem está diretamente ligada ao argumento do sujeito discursivo de que havia, já naquele momento, uma tendência favorável ao Movimento (Diretas já), pois eles se anteciparam na informação aos telespectadores. Essa tentativa de se mostrar a favor das Diretas vem reforçada pela informação do tempo da matéria: "dois minutos e 16 segundos", tempo considerado bastante significativo para a televisão, principalmente quando se leva em conta que o Jornal Nacional detinha uma grande audiência.

Os parágrafos seguintes vão mostrar as contradições internas do discurso, que insistem em fazer sentido, driblando o objetivo aparente do texto de tentar enfatizar algum "erro" da Rede Globo, a partir de duas linhas de raciocínio. Uma enfatiza que a Rede Globo sempre esteve presente como imprensa no acontecimento das Diretas, com informações sobre cada comício em nível local e nacional, utilizando tempos razoáveis nas notícias (os tempos são todos citados). A outra linha de raciocínio mostra que ao noticiar, tentava-se diminuir o caráter político do movimento, transformando-o num show de música e alguns discursos, tratando as duas práticas como algo semelhante. Mas o objetivo não era a festa a carnavalizar o movimento, minimizando seu papel contestatório ao regime ditatorial. Esse tipo de noticiário obedecia à recomendação do Diretor Presidente das Organizações Globo, que, segundo o próprio texto do arquivo, "temia que uma ampla cobertura da televisão pudesse se tornar um fator de inquietação nacional”:

A Globo registrou esses comícios pelas Diretas nos seus telejornais locais. Naquele primeiro momento, as manifestações não entraram nos noticiários de rede por decisão 
de Roberto Marinho. O presidente das Organizações Globo temia que uma ampla cobertura da televisão pudesse se tornar um fator de inquietação nacional.

Nesse movimento de retorno ao arquivo é preciso questionar o que seria uma "inquietação nacional" a ser evitada. A perda de poder dos poderosos, que tinha o diretor presidente a integrar o ciclo dos beneficiados? Provavelmente, mas sobretudo havia a necessidade de conter as massas que exigiam democracia, o fim do arrocho salarial, liberdade de expressão e novas políticas econômicas.

Num retorno histórico, podemos lembrar que esse gesto não é uma novidade na história brasileira, pois também líderes liberais dominantes, quando da defesa da escravidão, por exemplo, advogavam que ela teria de ser gradual para que não houvesse uma revolução dos negros. Ou seja, o objetivo foi sempre conter as massas com base na argumentação de que elas não sabem lidar com a liberdade, neste caso, com a "democracia".

O texto segue mostrando que o presidente da Organização Globo foi forçado a mudar a conduta dos noticiários, pois a história se fazia independentemente dos noticiários. Então, a reboque dos acontecimentos, os noticiários tornaram-se mais frequentes e de caráter nacional: "Mas a paixão popular foi tamanha que resolvemos tratar o assunto em rede nacional', afirmou ele em matéria publicada na revista Veja, de 5 de setembro de 1984".

Nessa versão do fato, compreende-se que aceitaram o irremediável, porém continuaram ainda tentando desqualificar o movimento. Segundo o texto: "A origem da confusão foi a chamada da matéria, lida pelo apresentador Marcos Hummel, que se referia ao comício da Sé como um dos eventos comemorativos do aniversário da cidade". O locutor leu a chamada: "Festa em São Paulo". O que percebemos é que a primeira tentativa de justificar o "erro" foi transferir para o locutor do jornal a responsabilidade pela leitura da matéria; já a segunda intenta minimizar o efeito das chamadas das matérias, que em comunicação têm o poder de direcionar a escuta do leitor, ou melhor, dos telespectadores.

Finalmente o texto encerra sua abordagem glorificando a presidência da Rede Globo e os seus diretores, que foram impedidos de se engajar nas manifestações em defesa do movimento pelas Diretas por conta da pressão dos militares que os ameaçaram até mesmo com a retirada da concessão: "Se por um lado segmentos da sociedade pressionavam a Rede Globo para se engajar nas manifestações pelas Diretas, por outro a emissora vinha sendo pressionada pelos militares a não cobrir os eventos".

O texto relata esses fatos e também convoca depoimentos de diversos colaboradores para referendar os argumentos da explicação (esclarecimento, desambiguização) do "erro", alguns, na época, tidos como simpáticos às Diretas Já.

Woile Guimarães, então diretor dos telejornais de rede, diz que ministros e generais ligavam para Roberto Marinho, ameaçando até mesmo retirar a concessão para o funcionamento da emissora. [...] José Bonifácio de Oliveira Sobrinho, o Boni, então vice-presidente de operações da TV Globo, confirma: "Naquele momento, a pressão sobre Roberto Marinho foi intensa. Foi uma frustração para mim e para toda a equipe de jornalismo, uma tristeza para o Armando Nogueira e a Alice-Maria, não poder fazer a cobertura de maneira adequada. Nós ficamos limitados pelo poder de audiência que a TV Globo tinha. Isso foi uma tristeza muito grande, mas naquele momento o Dr. Roberto não podia resistir."

Diante dos argumentos sobre os fatos, resta esclarecida a contradição produzida pelo "erro": "Nós ficamos limitados (...), foi uma tristeza muito grande, mas naquele momento 


\section{Conexão Letras}

o Dr. Roberto não podia resistir". Aquele que não quis divulgar o movimento, quando as decisões estão para ser tomadas, é colocado na atualidade como impedido de tê-lo feito naquele momento. Será que se essa emissora desde o início divulgasse a notícia do movimento, não teria contribuído para os 22 votos que separaram as Diretas da vitória naquele momento histórico?

Não dava mais para se recusar a participar diretamente. A multidão exigia que a emissora acompanhasse sua trajetória, e ela foi seguindo o movimento e, mesmo sob censura, a divulgação da campanha cresceu nos jornais e os articuladores do movimento conseguiram ter voz: "Em abril, a campanha empolgou definitivamente o país. No dia 10, cerca de um milhão de pessoas se reuniram na Candelária, no Rio de Janeiro. A Globo cobriu, então, com grande destaque o evento, dedicando-lhe quase uma hora da sua programação".

É interessante que nesse ínterim as cartas já estavam marcadas, e pela contagem dos votos já se sabia nas ruas que dificilmente as Diretas passariam pelo Congresso. Os militares, no entanto, temiam tumultos, proibiram manifestações e censuraram a imprensa; mas aqueles que não puderam fazer nada antes, agora se insurgiram e burlaram as proibições: "Apesar de estar impedida de transmitir ao vivo, a Globo conseguiu burlar a proibição, como relata a repórter Sônia Pompeu”. Ou seja, como o fato já estava decidido, todos se rebelaram: "O apresentador Cid Moreira informou que a Associação Brasileira de Emissoras de Rádio e Televisão, Abert, havia divulgado uma nota de protesto contra a censura de noticiário jornalístico vindo de Brasília".

Não se pode esquecer que "todo processo discursivo se inscreve numa relação ideológica de classe" (PÊCHEUX, 1988); assim, constatamos que venceu a prática dos poderosos de que mudanças não devem alterar as bases da sociedade, pois tudo tem de ser feito lenta e gradualmente, mudando, e não transformando, para que tudo permaneça na mesma ordem. O mercado agradece aos que zelam por sua supremacia, dando-lhes poder, mas sempre sob a sua orientação.

\section{2 "Erro": Debate Collor x Lula}

O segundo texto que buscamos para esta análise é o do "erro" sobre o debate Collor $x$ Lula. O texto do arquivo começa com um relato informativo do momento histórico que marca a primeira eleição direta para a presidência da República brasileira após 25 anos de ditadura militar. São citados os dez principais candidatos e apresentam-se links para que os leitores possam rever/ver as entrevistas realizadas com cada um. Em seguida, há a informação do resultado do primeiro turno, da seguinte forma:

No primeiro turno, Fernando Collor (PRN) saiu vitorioso, com 20,6 milhões de votos (o equivalente a $28 \%$ do total). Luiz Inácio Lula da Silva (PT) conseguiu 11,6 milhões de votos $(16,08 \%$ do total), conquistando a outra vaga do segundo turno numa disputa apertada com Leonel Brizola (PDT), que obteve 11,1 milhões de votos, apenas 454.445 a menos (em torno de $0,5 \%$ do total de votos).

A sequência discursiva assinala que o candidato Collor foi o primeiro colocado; na verdade, o texto imputa a esse candidato a qualificação de vitorioso para se referir a sua colocação, iniciando o processo de construção do efeito de sentido desejado, como veremos na continuação da análise. Assinala, o texto, que Collor obteve $28 \%$ dos votos, Lula $16,08 \%$, e ao se referir a Brizola, terceiro colocado, não informa o percentual, mas o número de votos e a diferença entre o segundo e o terceiro lugares, ressaltando a pequena 
diferença entre Brizola e Lula. A ausência do percentual de Brizola cria uma dificuldade ao leitor para calcular quanto foi de fato o percentual do terceiro colocado, pois necessitará calcular o número total de votos: "(Leonel Brizola (PDT), que obteve 11,1 milhões de votos, apenas 454.445 a menos (em torno de $0,5 \%$ do total de votos)".

Essa sequência tenta provocar um efeito de que para a maioria dos eleitores (somando os votos de Brizola e Lula), já que os dois praticamente empataram no primeiro turno, poderia ser qualquer um dos dois a concorrer no $2^{\circ}$ turno com o Collor "vitorioso". Essa forma de apresentação dos dados produz ambiguidade na descrição dos fatos ocorridos, pois mostra que tanto poderia ter sido o Brizola ou Lula, desqualificando, assim, o então candidato do PT. Se é apenas uma informação objetiva dos fatos ocorridos, por que apenas o terceiro candidato foi citado e não todos? Ou por que o texto não se referiu apenas aos dois que passaram para o segundo turno, já que os debates ocorridos para esse turno eram o objetivo do texto concernente ao "erro" da Memória da Rede Globo? A forma de constituição da sequência discursiva revela apenas que já houve um vencedor e dois outros candidatos que disputavam entre si o segundo lugar.

A ausência do percentual de Brizola e a falta de informação no arquivo (memória.globo) de que este candidato declarou quase que imediatamente após o resultado do primeiro turno seu apoio a Lula, e que por isso a soma dos percentuais dos dois ultrapassaria os do candidato já tido como vencedor do primeiro turno ${ }^{6}$ faz o leitor tomar as informações como evidências. A nosso ver, sem essas informações, o leitor que não acompanhou os acontecimentos - os jovens de hoje, principalmente -, mesmo sem saber como será a abordagem do "Erro", já "sabe" (desde já) que Lula não tinha a preferência dos eleitores e que havia um vencedor "desde sempre". Essa forma de dizer e não dizer parece amenizar o erro da emissora.

Seguindo o texto, são apresentadas informações sobre os dois debates que ocorreram antes do segundo turno, entre os dois candidatos em disputa ${ }^{7}$. Mas justamente as transmissões dos dois debates é que foram questionadas tanto pela população como pelos partidos. No entanto, segundo o próprio texto, os partidos não obtiveram êxito nas suas contestações, como afirma o arquivo: "As duas foram questionadas. A primeira, por apresentar um equilíbrio que não houve, e a segunda, por privilegiar o desempenho de Collor". É sobre a segunda transmissão e o conteúdo das matérias nos jornais de âmbito nacional que o texto do arquivo "Memória/Erro" incide, e se, por um lado, há o reconhecimento do "erro" da emissora, por outro, há também a tentativa de minimizar os seus próprios "erros".

O PT chegou a mover uma ação contra a emissora no Tribunal Superior Eleitoral. O partido queria que novos trechos do debate fossem apresentados no Jornal Nacional antes das eleições, como direito de resposta, mas o recurso foi negado. Em frente à sede da Rede Globo, no Rio de Janeiro, atores da própria emissora, junto com outros artistas e intelectuais, protestaram contra a edição.

O recorte tenta deixar claro que a justiça eleitoral (ESTADO) não considerou graves os erros; se os considerou, não acatou o pedido do PT ("o recurso foi negado"). Compreendemos que essa instituição de poder político-midiático, remetendo-se à decisão do tribunal Eleitoral, age para a conservação do status quo, que interessa aos poderosos, como afirmaram Marx e Marcuse em texto citado anteriormente. Por outro lado, a sequência

6 Não estamos afirmando que todos os eleitores que votaram em Brizola, após o anúncio do seu apoio à candidatura do PT, votariam automaticamente em Lula.

7 A matéria disponibiliza links dos debates e das edições do jornal Hoje e do Jornal Nacional. 


\section{Conexão Letras}

mostra como a emissora agiu democraticamente, tolerando e não punindo seus próprios artistas (atores da própria emissora, junto com outros artistas e intelectuais) por haverem participado das manifestações populares. Ou seja, o Estado mantém seu papel de agir "democraticamente" em prol dos poderosos, e a emissora se isenta da possibilidade de ter seu gesto de edição (leitura subjacente) questionado por todos os telespectadores; de outro modo, estes tomariam conhecimento efetivamente do que tinha havido em relação ao tempo e à montagem dos debates pelos telejornais de âmbito nacional.

A sequência do texto apresentada pelo site enfatiza as análises de outros jornais e de integrantes do Partido dos Trabalhadores:

No entanto, a própria liderança do PT, apesar de não admitir a derrota, reconheceu que Lula não se saíra bem no confronto com Collor. Como noticiou o Jornal do Brasil, antes mesmo de a edição do Jornal Nacional ser criticada, "um sentimento de frustração marcara as avaliações que o comando da campanha petista fazia sobre a participação de Lula no debate com o candidato do PRN"(JB, 16/12/1989). Seis anos depois, em entrevista à revista Imprensa, José Genoino afirmou que o desempenho de Lula tinha sido, realmente, ruim (Imprensa, 6/1995).

O discurso constrói uma cena discursiva com dois momentos completamente diferentes: a avaliação de um jornal que não cita a fala de ninguém, isto é, a posição discursivo-ideológica do jornal sobre o debate, e o depoimento de um membro do PT, que em outras circunstâncias, seis anos depois, admite que Lula não se saiu bem no debate. Na verdade, o efeito produzido é o de que, mesmo que se considere o "erro" da emissora, Lula perdeu o debate (havia sido "derrotado") - como se esse fato negasse a participação da Rede Globo em prol da candidatura de Fernando Collor no segundo turno.

O silenciamento maior está em não declarar o crescimento da candidatura de Lula, de não informar que na época dos debates havia uma expectativa das pesquisas de opinião de que estava se vivenciando um empate técnico. O efeito do discurso já estava montado desde a apresentação do Collor como vencedor no primeiro turno; logo, e como consequência, vencedor no pleito final. Só então o texto passa a dizer como foram realizadas as emissões, que atualmente necessitam ser corrigidas.

Utiliza-se uma explicação técnica, como se a edição simplesmente fosse realizada por jornalistas, sem nenhuma posição político-ideológica da emissora, tão só buscando-se a objetividade: "Os responsáveis pela edição do Jornal Nacional afirmaram, tempos depois, que usaram o mesmo critério de edição de uma partida de futebol, na qual são selecionados os melhores momentos de cada time". Essa forma explicativa funciona como se a edição de um debate em rede nacional entre dois candidatos à presidência da República na primeira eleição direta depois de anos de ditadura não mobilizasse as divergências de classes que anteriormente fizeram o presidente da Rede Globo admitir que as eleições diretas eram algo bastante complicado em um país que saia da ditadura, como visto no primeiro texto deste artigo: "O presidente das Organizações Globo temia que uma ampla cobertura da televisão pudesse se tornar um fator de inquietação nacional”.

Essa repetição do exercício de poder nos faz retomar Pêcheux, que ao analisar as eleições francesas de 1981, faz referência à ideia de jogo a partir do enunciado On a gagné, que circulou na mídia considerando François Mitterrand como "Vencedor":

Esse acontecimento que aparece como o 'global' da grande máquina televisiva, este resultado de uma supercopa de futebol político ou de um jogo de repercussão mundial (F. Mitterrand ganha o campeonato de Presidenciáveis da França), é o acontecimento 
jornalístico e da mass-media que remete a um conteúdo sócio-político ao mesmo tempo perfeitamente transparente (o veredito das cifras, a evidência das tabelas) e profundamente opaco. (PÊCHEUX, 2002, p. 19-20)

Coincidência. Tragédia. Farsa. Ante um acontecimento, ao mesmo tempo, transparente e opaco, a mídia busca lançar luzes em sua prática de leitura subjacente, sempre tida como evidência, por conta do ideal de objetividade e neutralidade. Para manter esse efeito, no caso em estudo, vemos que ela argumenta em relação ao tempo "dado" na TV e também com relação a sua função de levar informação aos cidadãos brasileiros.

Em relação ao tempo diferenciado que o candidato Collor utilizou, é completamente diferente a argumentação utilizada pelos elaboradores do "erro" no texto anterior a esse. Salientam que no início das Diretas Já, disponibilizaram um tempo muito próximo daquele subtraído ao candidato do PT, para assinalar que estavam dando cobertura às manifestações populares em favor das Diretas. Com isso a argumentação procura minimizar os danos das edições dos jornais pela emissora, sob o argumento de que um número maior de pessoas assistiu ao debate do que os que assistiram ao Jornal Nacional. O que foi silenciado foram os dados durante todo o debate, que só terminou às 24 horas, explicitando apenas o número de pontos. Comparou-se um debate de mais de três horas com uma edição de meia hora, mais ou menos, no horário nobre. Tantos dados aparentemente objetivos, e tanta desinformação ao leitor.

Além disso, segundo o Ibope, a audiência total do debate - somadas todas as emissoras que compunham o pool - foi de 66 pontos, maior do que a do Jornal Nacional do dia seguinte, que apresentou 61 pontos. Isso significa que o número de pessoas que assistiu ao debate na íntegra foi maior do que o daqueles que viram a sua edição no JN.

Quem garante como argumento válido que foi esse o número de pessoas que assistiram ao debate na íntegra? Apenas os editores do "erro". Como já dissemos, o objetivo do sujeito discursivo é minimizar as ações criticadas pela população, utilizando estratégias que isentam a Rede Globo de contribuir para a Vitória do candidato apoiado pelas elites e por partidos de caráter conservador, Collor de Mello. Estas são as estratégias discursivas:

$\checkmark$ Collor já era um vencedor desde o primeiro turno.

$\checkmark$ Lula quase não fica nem no segundo lugar no primeiro turno;

$\checkmark$ O erro foi da equipe de jornalismo (que tratou como um jogo), mas o debate não mudou o rumo das eleições:

$\checkmark$ Lula perdeu no segundo turno porque foi mal no debate.

$\checkmark$ Collor venceu os dois turnos.

Sintetizando:

\section{$\checkmark$ COLLOR FOI O VENCEDOR \\ $\checkmark$ LULA, O VENCIDO/DERROTADO}

Mas, apesar de tudo, a Rede Globo se penitencia e afirma que já mudou sua forma de tratar os debates políticos e que estes não terão mais edição: "o episódio provocou um inequívoco dano à imagem da TV Globo. Por isso, hoje, a emissora adota como norma não editar debates políticos; eles devem ser vistos na íntegra e ao vivo". Tudo parece ter sido resolvido/esclarecido (desambiguizado) para o próximo pleito de 2014. Será? 
Nessas retomadas do arquivo da mídia pela mídia - um jogo discursivo-ideológico se manifesta parecendo simplesmente uma justificava, de modo amenizado, do "erro" (mea culpa) do que se tinha dito e feito antes -, constatamos falhas e lacunas na polêmica dos enunciados. É que o modo de regularização da leitura dominante pressiona o sujeito discursivo para estabelecer os limites "programados" dos sentidos sobre os acontecimentos. Ou seja, houve "erro", mas para o momento histórico era "certo" fazer/dizer aquilo que se fez e se disse, logo não foi um "erro", apenas um deslize técnico.

Estamos às vésperas de uma nova eleição, com movimentos nas ruas e configurações de novos e dos mesmos arranjos político-partidários. Nesse simulacro do Arquivo que também conta a história do Brasil, pois, como diz Roudinesco (2006, p. 9), "o arquivo (destruído, presente, excessivo ou apagado) é a condição da história", vemos que se apagam as lutas de classes e "democraticamente" se concede ao "povo" "seus representantes". Sempre representantes do mesmo lugar e da mesma posição ideológica que representa os interesses dominantes. Por isso, questionamos: para quem se revelou esse dizer do Arquivo (retomado e esclarecido)? Para o "povo (cidadão) brasileiro"?

Com esses questionamentos, abrem-se outras inquietações que resistem aos efeitos da evidência da ideologia dominante, pois persistem furos nesses arquivos que desejam saturar/tranquilizar os sentidos conflitantes. Estes teimam em não coincidir com os interesses dominantes e escapam à regularização do "arquivo" que se quer no lugar da História.

\section{Referências}

MAGALHÃES, Belmira \& SILVA SOBRINHO, Helson. "Erro" no apoio ao golpe de 64: sujeitos enfrentam-se nesse acontecimento discursivo. Revista Letras. Universidade Federal de Santa Maria. No 48. Jan./jun. 2014.

MARCUSE, Herbert. Prólogo. In MARX, Karl. O 18 de Brumário de Luís Bonaparte.

São Paulo: Boitempo, 2011.

MARIANI, Bethania. Arquivo e língua nacional: percursos de pesquisa. In: TEDESCO, M.; MEDEIROS, V. (Orgs.). Travessias nos estudos de lingua portuguesa: homenagem a Evanildo Bechara e Olmar Guterres. Rio de Janeiro: Dialogarts, 2010.

MARX, Karl. O 18 de Brumário de Luís Bonaparte. São Paulo: Boitempo, 2011. ORLANDI, Eni. As formas do silêncio no movimento dos sentidos. Campinas: Editora da Unicamp, 2002.

ORLANDI, Eni. Interpretação. Petrópolis: Vozes, 1996.

PÊCHEUX, Michel. Ler o arquivo hoje. In ORLANDI, Eni. Gestos de leitura: da história no discurso. 2. ed. Campinas, SP. Editora da Unicamp, 1997.

PÊCHEUX, Michel. O Discurso: estrutura ou acontecimento. 3. ed. Campinas, SP:

Pontes, 2002.

PÊCHEUX, Michel. Semântica e Discurso. Campinas, SP: Editora da Unicamp, 1988. ROUDINESCO, Elisabeth. A análise e o arquivo. Rio de Janeiro: Jorge Zahar, 2006. ŽIŽEK, Slavoj. Primeiro como tragédia, depois como farsa. São Paulo: Boitempo, 2011. 